\title{
Japan seeks funding for new drilling ship
}

[TOKYO] Earth scientists and deep-sea drilling engineers from 17 countries, meeting in Tokyo last week, unanimously endorsed a Japanese plan to build a new deep-sea drilling ship. The ship is intended to play a key role in the future of the international Ocean Drilling Program (ODP) beyond 2003, when the current phase of the programme ends.

The proposed ship, part of a Japanese initiative called 'Ocean Drilling in the 21st Century', would adapt drilling technology from the petroleum industry to allow drilling to much greater depths in the Earth's crust and in more difficult geological terrain than is possible with the current programme's drilling ship, the JOIDES Resolution.

In particular, the new ship would use 'riser technology', in which the drilling stem is encased in a rigid pipe that would rise off the sea floor in water depths of up to 2,500 metres and extend up to the ship. The riser pipe would allow the circulation of drilling mud to facilitate drilling to depths of up to $7 \mathrm{~km}$ beneath the sea bed - several times the maximum depth achieved so far in the ODP.

The ship, first proposed by Japan's Science and Technology Agency (STA) in 1990 (see Nature 346, 307; 1990), has become critical to the ODP's future. Last year, it was effectively incorporated into the programme's longterm plan, as this calls for a two-ship programme beyond 2003 with a riser-equipped drilling ship and another ship similar to the JOIDES Resolution.

But it remains to be seen whether the ODP partners, which include the United States, Japan, France, Germany, Russia, Canada and the United Kingdom, will be prepared to provide the extra funds needed to run the ambitious programme - even if the Japanese ship, which is expected to cost about US $\$ 500$ million, gets budgetary approval.

The Tokyo meeting, called the Conference on Cooperative Ocean Riser Drilling (CONCORD), was timed to give maximum support to STA's attempts to win money for the ship in the agency's budget request for the next fiscal year, due to be drawn up at the end of August. But according to Hajime Kinoshita, director of the deep-sea research department of the Japan Marine Science and Technology Center, which would operate the ship, the agency has "more or less given up" hoping for a budget for the ship next year because of the government's mood of fiscal restraint.

Instead, it will lobby for a budget of about US\$35 million to build drilling equipment for the ship in the hope that this will lead to money to design the ship in the following fiscal year. That means the ship cannot be completed until 2003 at the earliest.

The two-ship programme will cost about US $\$ 120$ million a year to run, nearly three times ODP's current annual budget of US $\$ 45$ million, more than half of which comes from the US National Science Foundation. Last year, France and the United Kingdom considered withdrawing from the programme because some felt it was not giving sufficient value for money and that much ODP research was ending up in 'grey literature' in ship reports (see Nature 379, 193; 1996). But according to Kiyoshi Suyehiro of the Ocean Research Institute of Tokyo University, one of CONCORD's organizers, France and the

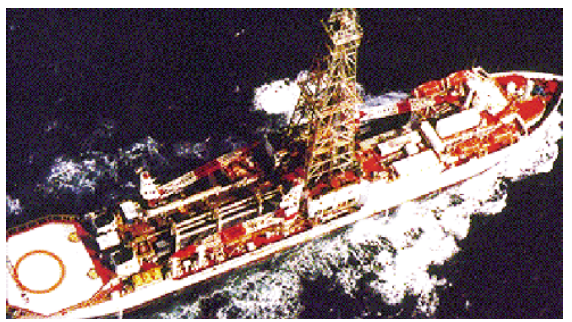

The next generation of drilling ship will drill deeper than JOIDES Resolution (above).

United Kingdom are now fully commited to staying with the ODP until at least 2003.

Xavier Le Pichon, of France's Laboratoire de Géologie of the Ecole Normale Supérieure, said in a keynote speech that though there had been "strong criticism" of the ODP, including some by himself, the ocean drilling community is making "major efforts to change".

Jim Briden, director of the Environmental Change Unit at the University of Oxford, and the UK representative on the ODP executive, said that the United Kingdom "fully supports" expanding the programme. He acknowledged that getting the required funds would bea "challenge", but was confident that six years is long enough in which to do this.

Briden says that two additional sources of funds have been identified: industry and the European Commission. "There is nothing in current EC research programmes that matches the ODP's work," he said. He added that negotiations had begun with Europe's oil industry, which is interested in the new riser drilling technology.

Le Pichon stressed the need to involve a wider community of scientists in the ODP's future, including those involved in the International Continental Scientific Drilling Program. Indeed, it was generally recognized by participants that more countries will have to join the ODP if it is to raise the funds for a two-ship programme. China, for example, was represented at the meeting, and is about to become an ODP member, but with a greatly reduced membership fee.

Japan is also looking to ODP partners to help with the costs of their proposed ship through, for example, the provision of shipboard laboratory and onshore facilities.

The meeting identified several scientific goals for the new ship, including the extension of studies of the climate variability record to 180 million years; the search for bacteria deep in marine sediments and the ocean crust; and drilling into the upper mantle through the ocean crust. But the meeting decided unaminously that drilling should initially concentrate on the active seismic region in the subduction zone along Japan's coast so as to gain a better understanding of earthquakes through direct long-term observation. DavidSwinbanks international research community, as other countries do not grant their industries a similar privilege (see Nature 387, 536; 1997).
In a letter to the research ministry, the Förderverein says that both genomic and by the waiver of its privileged access. "This is Technologies Licensing at Hoechst AG in Frankfurt am Main, a member company of confidence between pharmaceutical companies and academic scientists, encouraging the latter to make use of patents and licensing agencies."

The waiver is likely to resolve the conflict over the rules of Germany's Human Genome Project. But because differences between European and US patent laws lie at the heart of the problem - in particular, the existence of a 'grace period' under US law for filing patents - the Förderverein says it sees "a clear need to harmonize international patent law".
Quirin Schiermeier 